International Journal of English Literature and Social Sciences
Vol-6, Issue-1; Jan-Feb, 2021
Journal Home Page Available: https://ijeab.com/
Journal DOI: $10.22161 /$ ijels

\title{
Exploring the function of literature in the light of Mandela's Long Walk to freedom
}

\section{Bazimaziki Gabriel}

University of Rwanda, College of Education, Department of Humanities and Language Education, PO Box 55, Rwamagana- Rwanda.

Received: 11 Nov 2020; Received in revised form: 09 Jan 2021; Accepted: 21 Jan 2021; Available online: 07 Feb 2021

(C)2021 The Author(s). Published by Infogain Publication. This is an open access article under the CC BY license

(https://creativecommons.org/licenses/by/4.0/).

\begin{abstract}
Literature is a reflection of reality and is a mirror of what happens in the world we live. Authors of literature convey various messages depending on their goals for each. Their expression offeelings, emotions and thought about human lives intends to teach society about society. In this descriptive essay as anchored on thematic analysis of Nelson Mandela's autobiography "Long Walk to Freedom", the author's intent was to explore how one' life challenges are not only a historical experience for him/herself but also a didactic tool to readers and contemporary society as well. Discussion in this paper demonstrated how well the message conveyed in non - fictional prose plays a significant role as they teach history, social and cultural values, commitment, patience and perseverance. The study reveals that sometimes a success of the present time springs from a painful but enduring past.
\end{abstract}

Keywords-Literature, art, non-fictional prose, autobiography, Mandela, long walk to freedom, function of literature.

“When a man is denied the right to live the life he believes in, he has no other choice but to become an outlaw"- Nelson Mandela

\section{INTRODUCTION}

Human beings and the world are central for the word art. Understanding exactly what literature is has always been a challenge; and pinning down a definition has proven to be quite difficult. In fact, at times one seems to be reduced to saying, "I know it when I see it," or perhaps, "Anything is literature if you want to read it that way" (Meyer, 1997). Elsewhere, in order to understand well the term literature, one must take much consideration into culture and social values as well discussed in Gautam (2014) that literature is generally and inherently considered as a source of our understanding of the society and its values. She further contends that scholars of every field consider literature as a valid source of history and background information, an idea parallel to Bazimaziki
(2017) where literature is considered as a didactic tool, an educational mirror by and large.

While the international human rights stipulate that human beings should be free from any violence, in many parts of the globe, people are often affected by factors such as discrimination reflected by inequality, injustices, oppression and other rights denial. These are challenges that are part of life and are inevitable where human beings live. That is why authors of literature express their feelings, emotions and thoughts about how human beings behaved, or behave towards their fellow human beings; so that the readers and society can learn from it. Kakarla (2020) asserts that literature and society have remained inseparable from each other, for Literature cannot sustain without society, and likewise society too cannot be unnoticed in literary pieces in one way or 
another. He further explains that when we read literature, we likewise find critical contrasts and this permits us to investigate another's message or life, even those isolated from us by time and social boundaries. Literature is thus important for both individual and society as well. Mphahlele (1974) says that literature functions at two levels such as personal and societal levels. He posits that at individual level literature functions as a point of reference for the reader while at social level it functions as a social necessity; as it is a vehicle of religion, mode of production, source of education, thus a social cultural function.

In similar view, Bazimaziki (2020) found out that literature and human life cannot be distanced totally as one produces another. He posits that literary genres are mirrors through which human beings worldwide perceive their picture, their ills and mores. These genres reflect reality or what is currently happening in many parts of the globe as it happened and will always take place in a better or worse way. This implies that human behaviour on earth is revealed through forms embodied in the four main literary branches such as Oral literature, Prose, Poetry and Drama, and following Dubey (2013), literature combined with culture and other facets of society -both abstract and concrete, not only presents impalpable subjects like alienation, assimilation and transformation in society but also reflects the palpable issues ,such as ,historical, political and social facts.

$\mathrm{Be}$ that as it may, literature is seen as an artistic use of language to depict human beings and the world around them and to that end, Bazimaziki (2017) and Bazimaziki et al.(2019a) contend that literature plays various functions including without limitation to historical, socio- cultural, patriotic, and didactic as well. It is thus a didactic tool to society, about society's past, present for the future. It is all about human life reflected through fiction and nonfiction genres. The latter attracts the interest of the author in this study with particular emphasis on Long Walk to Freedom, an autobiography of Nelson Mandela which recounts his life experience.

\section{AIMS OF THE STUDY}

The aim of this paper was to describe the function of literature with particular focus on non-fictional prose. Literary analysis was carried in the light of Mandela's Long Walkfor Freedom. The author wanted to demonstrate that a long walk is a difficult journey paved with hardships and challenges, a long painful journey to a successful destination. The study sought to find out that any quest for freedom is a struggle whereby the protagonist must be committed, face enemies but also win the supports of helpers who wish the good of the society.

\section{Study questions}

The study was guided by three main questions: (1) what is Literature about? (2) What is the function of Literature? (3) What is the message does Nelson Mandela's Long Walk to Freedom convey to contemporary society?

\section{THEORY AND METHOD}

Literary critics provide two leading theories of literature namely expressive theory and didactic theory. The expressive theory of literature regards literature as stemming from the author's inner being, and similarly depends on a notion of mirroring. According to this theory, literature is an expression of the author's feelings and emotions. For the didactic theory, literature is a source of knowledge, insight, wisdom, and perhaps prophecy. For the present paper, both theories were deemed significant in the light of the primary and secondary sources which led the discussion. Further, the methodology was dictated by the nature of the study designed as interpretive and descriptive focused on thematic analysis. The study inherently considered a question raised in Dubey (2013) whether the occurrences taking place in persons' lives become a catalytic agent in literary creation, with particular interest in the autobiography of Nelson Mandela.

\section{DISCUSSION}

Generally, literature is a mode of expression that embodies human emotions and thoughts in specific forms, taking all its materials from life (Rhee, 2011) and its main function is knowledge sharing as it helps the audience or readers to know what happened and is happening in the world they live. As such, many literary genres deal with human life experiences like non-fictional which deal with real life stories about people affected by real events in real settings. Autobiographies, for example, embody history as they recount the life experience of their realistic authors. Such genres convey various messages connected with the authors' step by step life from his/her infancy to their more advanced age. One will therefore draw important lessons and ape in need or blame according to their way of perception. Additionally, patriotic function cannot be left out as literature can serve as a tool to enhance national unity. Another function is didactic as discussed before. This is concerned with teaching connected with communication between the author and the reader about the 
occurrences or the events taking place in a society. All these functions are intertwined in that they involve human beings.

When Mandela (1995)says, "My father has sometimes been referred to as the prime minister of Thembuland during the reigns of Dalindyebo, the father of Sabata, who ruled in the early 1900s, and that of his son, Jongintaba, who succeeded him", it is history revealing lineage, reign and successions of fathers by their descendants. In the opening pages, the book conveys the message about the role of the father to a male child. Mandela says that despite that her mother was the center of her existence; he defined himself through his father. In African culture, a father could train and inspire his son by providing him with education, by teaching him wisdom and encouraging him in what they are committed to doing so that they can do it confidently. We are told that Mandela's fatherGadla Henry Mphakanyiswa, was an influential and respected man due to his constructive pieces of advices to various people including Kings and other important personalities. Despite that he hadn't formal education, he was an excellent consultant and was trusted to make right decisions when consulted. The author says,

"He was an acknowledged custodian of Xhosa history, and it was partially for that reason that he was valued as an adviser. My own interest in history had early roots and was encouraged by my father. Although my father could neither read nor write, he was reputed to be an excellent orator who captivated his audiences by entertaining them as well as teaching them. [...] My father, and a few other influential chiefs, had the great respect for education that is often present in those who are uneducated."(p.1)

As discussed earlier, literature plays a social- cultural function. In traditional Africa, having many wives was a very important aspect of African culture especially for men of big titles. Mandela's father was no exception. He had three wives living in their kraals- (homestead) for each as he said,

"All told, my father had four wives, the third of whom, my mother, Nosekeni Fanny, the daughter of Nkedama from the amaMpemvu clan of the Xhosa, belonged to the Right Hand House. Each of these wives - the Great Wife, the Right Hand wife (my mother), the Left Hand wife, and the wife of the Iqadi or support house -had her own kraal. A kraal was a homestead and usually included a simple fenced-in enclosure for animals, fields for growing crops, and one or more thatched huts"( Mandela, 1995:1 )

In many cultures too, it is a social act to look after a friend's children when their parents is dead. This is a take your next door's kids as yours which reflects strong ties and cements friendship, thus preserving human values of "a care - attitude". For example, shortly after his father's death, Mandela was brought up by another guardian in recognition of his father's service to him (guardian) as well explained in the words below:

"I learned later that, in the wake of my father's death, Jongintaba had offered to become my guardian. He would treat me as he treated his other children, and I would have the same advantages as they. My mother had no choice; one did not turn down such an overture from the regent. She was satisfied that although she would miss me, I would have a more advantageous upbringing in the regent's care than in her own. The regent had not forgotten that it was due to my father's intervention that he had become acting paramount chief."(Mandela, 1995)

From the above words, one can draw an important lesson that we could do as we would like to be done by. Further, it is important that people be grateful and pay services as or better than they were offered. Guardians' treatment to others' children like their own reflect a culture of human right promotion, children rights specifically. In African culture, it is often said that a child is a king; meaning that any child should be treated well because they belong to the nation. When bringing them up without any discrimination, one is educating future leaders for a nation much as Jongintaba, interestingly but unknowingly, educated a freedom fighter for the oppressed, a future president for a country where "the policy of apartheid had created a deep and lasting wound among its people" which he was ready to heal as he said:

"In life, every man has twin obligations obligations to his family to his parents, to his wife and children; and he has an obligation to his people, his community, his country. In a civil and humane society, each man is able to fulfill those obligations according to his own inclinations and abilities. But in a country like South Africa, it was almost impossible for a man of my birth and color to fulfill both of those obligations. In South Africa, a man of color who attempted to live as a human being was punished and isolated. In South Africa, a man who 
tried to fulfill his duty to his people was inevitably ripped from his family and his home and was forced to live a life apart, a twilight existence of secrecy and rebellion. I did not in the beginning choose to place my people above my family, but in attempting to serve my people, I found that I was prevented from fulfilling my obligations as a son, a brother, a father, and a husband."(Mandela, 1995)

Actually, when men, women, black and white waited for more than half a century to cast their vote saying that they felt like human being for their first time in South Africa ( Mandela cited in Rodriguez, 2004), what is meant is that there had been human rights violence for a long. Similarly, when MacNab (2002) expresses what it takes to survive, he demonstrates that torture and imprisonment not only mines one's life but also provides them with relevant training, experience and knowledge for future use. In his introduction to We Die Alone, the author reveals a story of one man's ability to endure the worst imaginable and survive, and he further recommends to anyone interested in the resilience of the human spirit that the fundamental spirit to survive lies within us all.

In Long walk to Freedom, we are told a similar story of Mandela, the protagonist of human rights. According to Brookfield (2007), the author (Mandela) describes a scene about how an iconic political activist and freedom fighter reflected on, and sometimes modified, several core assumptions at the heart of his struggle to overturn the White supremacist, minority hegemony and create a free South Africa. It is a book reflecting human beings oppressed by their fellow human beings. We are told that Black people were oppressed and discriminated a great deal hence Mandela vowed to fight for their rights, to make their voice be heard, thus a freedom struggle. In the same token, Zhou (2020) explained that Long Walk to Freedom describes Mandela as the most prestigious prisoner in the world who experienced twenty-seven years of hardship in jail in South Africa. His four years of striving for freedom for his countryman out of jail won him the president in South Africa and was also spoken highly of his lofty virtue by the world. He confirms that South Africa, under Mandela's leadership, turned to be democratic from a country of long-term barbarity and atrocious apartheid. By and large, this is history which implies a historical function of literature. In fact, twenty seven years of sufferings endurance requires exceptional courage. During that period, the author tasted the ills but he was surprisingly released and later campaigned for a presidential position. It is a difficult journey for an elixir, thus a heroic journey of liberation that benefited his community as he said "When I walked out of prison that was my mission, to liberate the oppressed and the oppressor both". It is an educational mirror not only to Africans ahead of time, but also new current and future generations to prosper, to fight for the right cause, to endure the painful situations, however they may be , all along their journey to a destination.

\section{CONCLUSION}

The aim of this essay was to carry out a literary analysis with an attempt to answer three research questions. The first question was concerned with what Literature is about. The study reveals that literature is concerned with the use of language artistically to express one's feelings or thoughts. It is an art which depicts human beings and the world around them. It reflects society and is consequently a mirror of society, a learning tool for human beings about what happened, and/or is happening as a result of human being acting fairly or unfairly to their fellows. A point made here goes side by side with Bazimaziki et al. (2019b) that literature depicts human beings coping with the world around them. Concerning the second question, the study sought to explore the function of literature. It was found that literature plays various roles. First, it is a vehicle of history as many fictional and non- fictional works put it right. Second, literature plays a socio-cultural role as many novels, poems and plays convey the social and cultural issues. Literature is from that perspective an educational mirror. The last question in this paper was concerned with the message that Nelson Mandela's autobiography conveys. Discussion revealed that Long Walk to Freedom chronicles the life experiences of the protagonist. He was committed to bringing change, to struggle in favour of the oppressed. The story shows that freedom fighting is energy and time consuming task which requires endurance, commitment and courage as well. It is a quest among other difficult journeys undertaken by story protagonists as found in literature. In a word, literature is considered as a didactic material, an educational tool because through it people learn how to live.

\section{REFERENCES}

[1] Bazimaziki, G. (2017). Depiction of Human Society through Epic Literary Genres: A Comparative Perspective of the Function of two African Heroic Epics. International Journal of English and Literature (IJEL). 8(5), 63-73.

[2] Bazimaziki, G. (2020). Reflection on Literature as a Mirror and a Didactic Mode to Society: A Mini-review of Multi-genres. 
Asian Journal of Language, Literature and Culture Studies,3(1): 45-52.

[3] Bazimaziki, G., Bisamaza E., Ndayishimiye J. Leonard, Nsabumuremyi L. (2019a). The Socio-didactic Function of Oral Literary Genres: A ParemiologicalPerspectivism of Selected Ethical Proverbs. International Journal of Linguistics Literature and Translation 2(2), 39-46.

[4] Bazimaziki, G., Mukadisi, F., Twahirwa J.B. (2019b). Acquired human violence and Taught Humanhood in South African fiction: A perspectivism of the protagonists in Alex la Guma's A Walk in the Night and Peter Abrahams' Mine Boy. Asian Journal of Language, Literature and Culture Studies.2(2),1-5. Available from http://www.journalaj12c.com/index.php/AJL2C/article/view/3 $\underline{0101}$;

[5] Brookfield, S. (2007)."Radical Questioning on the Long Walk to Freedom: Nelson Mandela and the Practice of Critical Reflection," Adult Education Research Conference. https://newprairiepress.org/aerc/ 2007/papers/16

[6] Dubey, A. (2013). Literature and Society. IOSR Journal of Humanities and Social Science 9(6):84-85. Available from https://www.researchgate.net/publication/23684377.

[7] Gautam, S. (2014). Can Literature be used as a Source on Changing Social Scenario? In the 6th National Conference on Innovative Approaches in Management, Law and Social Sciences for Sustainable Growth and Development at Manav Bharti University, Solan, Himachal Pradesh.

[8] Kakarla Sai M. (2020). Literature and its role in shaping the society. An International Multidisciplinary Double-Blind Peer-reviewed Research Journal, 2(2) ISSN: 2582-1962.

[9] Mandela, N. (1995). Long Walk to Freedom: The Autobiography of Nelson Mandela. London: Brown and Company.

[10] McNab, A. (2002). We Die Alone: An introduction. New York: Canongate Books.

[11] Meyer, J. (1997). "What is Literature? A Definition Based on Prototypes," Work Papers of the Summer Institute of Linguistics, University of North Dakota Session: Vol. 41, Article 3. DOI: 10.31356/silwp.vol41.03Available at: https://commons.und.edu/sil-work-papers/vol41/iss1/3

[12] Mphahlele, E. (1974). The Function of Literature at the Present Time: The Ethnic Imperative. Transition, (45), 47-53. Doi: $10.2307 / 2935025$.

[13] Read, James H. (2010). Leadership and power in Nelson Mandela's Long Walk to Freedom, Journal of Power, 3:3, 317 339, DOI: 10.1080/17540291.2010.524792

[14] Rhee, J. (2011). On "The value of Literature) and "What is Literature?" Azalea: Journal of Korean Literature\& Culture, 4283-285.Doi:10.1353/aza.2011.0003.

[15] Rodríguez, H. (2004). A "Long Walk to Freedom" and Democracy: Human Rights, Globalization, and Social Injustice. Social Forces, 83(1), 391-412. Retrieved January 23, 2021, from http://www.jstor.org/stable/3598243
[16] Zhou, J. P. (2020). An Analysis of Long Walk to Freedom from the Perspective of Transitivity System. Open Journal of Modern Linguistics, 10, 195-202. https://doi.org/10.4236/ojml.2020.103012 